\title{
Allelopathic effects of the aquatic macrophyte Ceratophyllum demersum L. on phytoplankton species: contrasting effects between cyanobacteria and chlorophytes
}

Efeitos alelopáticos da macrófita aquática Ceratophyllum demersum L. sobre espécies fitoplanctônicas: efeitos contrastantes entre cianobactérias e clorófitas

Cihelio Alves Amorim¹ (D), Rafael Henrique de Moura-Falcão ${ }^{1}$, Celina Rebeca Valença ${ }^{1}$,

Vitor Ricardo de Souza ${ }^{1}$, Ariadne do Nascimento Moura ${ }^{1 *}$

${ }^{1}$ Programa de Pós-graduação em Botânica, Departamento de Biologia, Universidade Federal Rural de Pernambuco - UFRPE, R. Manuel de Medeiros, s/n, Dois Irmãos, CEP 52171-900, Recife, PE, Brasil

*e-mail: ariadne_moura@hotmail.com

Cite as: Amorim, C.A. et al. Allelopathic effects of the aquatic macrophyte Ceratophyllum demersum L. on phytoplankton species: contrasting effects between cyanobacteria and chlorophytes. Acta Limnologica Brasiliensia, 2019, vol. 31, e21.

Abstract: Aim: To assess the allelopathic effects of the submerged macrophyte Ceratophyllum demersum on four strains of phytoplankton species: two cyanobacteria (Microcystis aeruginosa microcystin producing and M. panniformis - non-microcystin producing), and two chlorophytes (Ankistrodesmus falcatus and Raphidocelis subcapitata). Methods: A coexistence experiment between C. demersum and the four strains was carried out for six days, with eight treatments and three replicates. The strains were cultivated in ASM1 culture medium, under controlled laboratory conditions. Two treatments were assigned for each strain, one with 6 g. $\mathrm{L}^{-1}$ of the macrophyte, and the control without the plant. Biomasses and growth rates of the strains were evaluated every two days, which were compared through the T-test and two-way ANOVA, respectively. Results: The results varied among the strains, with toxic $M$. aeruginosa being intensely inhibited by $C$. demersum, with a decrease of $99.5 \%$ in its biomass $(p<0.001)$, while non-toxic $M$. panniformis was less affected by the allelochemicals, with a reduction of $86.2 \%(p<0.001)$. Ankistrodesmus falcatus delayed its growth when in coexistence with the macrophyte, decreasing its biomass in $50.4 \%(p<0.01)$, while $R$. subcapitata was not altered $(p>0.05)$. In coexistence with $C$. demersum, $M$. aeruginosa exhibited the lowest growth rates $\left(-0.65 \mathrm{~d}^{-1}\right)$, followed by $M$. panniformis $\left(-0.15 \mathrm{~d}^{-1}\right)$, A. falcatus $\left(0.19 \mathrm{~d}^{-1}\right)$, and $R$. subcapitata $\left(0.34 \mathrm{~d}^{-1}\right)$, with significant differences between all strains $(p<0.001)$. Microcystis aeruginosa presented higher inhibition rates than M. panniformis ( $\mathrm{p}<0.001)$, as well as, A. falcatus was more inhibited than $R$. subcapitata $(\mathrm{p}<0.05)$. Conclusions: The presence of microcystins could influence the allelopathic responses of $C$. demersum, that may release more allelochemicals in coexistence with toxic strains of $M$. aeruginosa. Accordingly, C. demersum can be used in biomanipulation strategies to control toxic and non-toxic cyanobacterial blooms, without damaging other phytoplankton species, like chlorophytes.

Keywords: allelopathy; biomanipulation; coexistence experiments; control of cyanobacteria; submerged macrophytes.

Resumo: Objetivo: Avaliar os efeitos alelopáticos da macrófita submersa Ceratophyllum demersum sobre quatro cepas de espécies fitoplanctônicas: duas cianobactérias (Microcystis aeruginosa - produtora de microcistinas e M. panniformis - não produtora) e duas clorófitas (Ankistrodesmus 
falcatus e Raphidocelis subcapitata). Métodos: Foi realizado um experimento de coexistência entre C. demersum e as quatro cepas, durante seis dias, com oito tratamentos e três réplicas. As cepas foram cultivadas em meio ASM1, sob condiçóes laboratoriais controladas. Foram designados dois tratamentos para cada cepa, um com 6 g.L $\mathrm{L}^{-1}$ da macrófita, e um controle sem a planta. Biomassas e taxas de crescimento das cepas foram avaliadas a cada dois dias e comparadas pelo teste-T e ANOVA two-way, respectivamente. Resultados: Os resultados variaram entre as cepas, sendo a cepa tóxica de $M$. aeruginosa intensamente inibida por $C$. demersum, com uma reduçáo de $99,5 \%$ na sua biomassa ( $p<0,001$ ), enquanto a cepa não tóxica de $M$. panniformis foi menos afetada pelos aleloquímicos, com uma redução de 86,2\% ( $p<0,001)$. Ankistrodesmus falcatus retardou seu crescimento em coexistência com a macrófita, reduzindo sua biomassa em 50,4\% ( $p<0,01)$, enquanto que $R$. subcapitata não foi afetada $(p>0,05)$. Em coexistência com $C$. demersum, $M$. aeruginosa apresentou as menores taxas de crescimento $\left(-0,65 \mathrm{~d}^{-1}\right)$, seguida de $M$. panniformis $\left(-0,15 \mathrm{~d}^{-1}\right)$, A. falcatus $\left(0,19 \mathrm{~d}^{-1}\right)$ e $R$. subcapitata $\left(0,34 \mathrm{~d}^{-1}\right)$, com diferenças significativas entre todas as cepas $(p<0,001)$. Microcystis aeruginosa apresentou maiores taxas de inibição que Microcystis panniformis ( $\mathrm{p}<0,001)$, bem como, A. falcatus foi mais inibida que $R$. subcapitata $(\mathrm{p}<0,05)$. Conclusóes: $\mathrm{A}$ presença de microcistinas pode afetar as respostas alelopáticas de $C$. demersum, que pode liberar mais aleloquímicos em coexistência com cepas tóxicas de $M$. aeruginosa. Portanto, $C$. demersum pode ser utilizada em estratégias de biomanipulação para controle de floraçôes de cianobactérias tóxicas e não tóxicas, sem causar danos às demais espécies fitoplanctônicas, como as clorófitas.

Palavras-chave: alelopatia; biomanipulação; experimentos de coexistência; controle de cianobactérias; macrófitas submersas.

\section{Introduction}

In the last few decades, the rising temperatures linked to an excessive input of nutrients in the water bodies have supported the occurrence of cyanobacterial blooms (Kosten et al., 2012; Paerl \& Otten, 2013). These blooms have become a frequent global problem for the public supply reservoirs, which can be composed of species that produce cyanotoxins, such as hepatotoxins, neurotoxins, and dermatotoxins (Wiegand \& Pflugmacher, 2005). Among the most frequent and harmful cyanobacteria, the genus Microcystis presents bloom records in 108 countries, 79 of which report the production of microcystin (Harke et al., 2016).

Microcystins are the most extensively studied cyanotoxins in the world, which are considered the most frequent and lethal. Therefore, the World Health Organization (WHO) and the Brazilian Ministry of Health established a tolerable limit of $1.0 \mu \mathrm{g} . \mathrm{L}^{-1}$ of microcystins in waters destined for public supply (Chorus \& Bartram, 1999; Brasil, 2011). These regulations were created after the "Tragedy of Caruaru", known worldwide as the largest case of human poisoning by microcystins, in which 76 renal patients died after using water contaminated with microcystins at a hemodialysis clinic in Caruaru, Pernambuco, in 1996 (Carmichael et al., 2001). In the Brazilian Semiarid region, the occurrence of microcystin-containing cyanobacteria blooms is still more recurrent (Bittencourt-Oliveira et al., 2014; Lorenzi et al., 2018), which is certainly due to the climatic and eutrophication conditions of the water bodies in this region that favor the occurrence and establishment of these blooms (Moura et al., 2018).

One potential solution for the control of cyanobacterial blooms includes the use of submerged aquatic macrophytes as a biomanipulation alternative since they can efficiently decrease phytoplankton growth (Zuo et al., 2012). These plants help to maintain clear conditions in shallow lakes (Scheffer et al., 1993, 2003; Hilt \& Gross, 2008). Their mechanisms of action are related to the reduction of nutrient concentrations in the water column, which is essential for phytoplankton growth; reduction of sediment resuspension; and supply of refuge to zooplankton and macroinvertebrates (Scheffer et al., 1993; Mulderij et al., 2007), which are efficient phytoplankton consumers (Amorim et al., 2019). In addition, these plants can also release allelochemicals in the water, acting on the inhibition of planktonic and epiphytic algae (Erhard \& Gross, 2006; Hilt \& Gross, 2008).

Several studies have shown the allelopathic potential of aquatic macrophytes on cyanobacteria and microalgae in laboratory studies, with submerged macrophytes being more efficient (Mohamed, 2017). In this context, cyanobacteria are more sensitive to allelochemicals when compared to chlorophytes (Körner \& Nicklisch, 2002; Erhard \& Gross, 2006; Zhu et al., 2010). However, Chang et al. (2012) pointed out that Myriophyllum verticillatum $\mathrm{L}$. is able to inhibit the growth of Microcystis aeruginosa (Kützing) Kützing in pure cultures, however, this cyanobacterium is stimulated when co-cultivated with the green 
algae Desmodesmus armatus (Chodat) E.Hegewald. Besides, Švanys et al. (2016) showed that non-toxic strains of $M$. aeruginosa are more sensitive to tannic acid, an allelochemical isolated from aquatic macrophytes. However, Amorim (2017) found that when coexisting, toxic strains of Microcystis are more affected by submerged macrophytes, as the stress caused by the microcystins promotes a greater release of allelochemicals by aquatic plants.

Considering the high occurrence of cyanobacterial blooms in the Brazilian Semiarid region, in addition to the expectation of increasing of the blooms for the coming years due to climate change and eutrophication, more studies aiming to control cyanobacterial blooms using aquatic macrophytes are needed. Thus, the aim of this study was to evaluate the allelopathic potential of the aquatic macrophyte Ceratophyllum demersum L. on the growth of cyanobacteria species, with one toxic and another non-toxic strain, and chlorophytes to understand the role of allelochemicals on different phytoplankton species.

\section{Material and Methods}

\subsection{Phytoplankton organisms, submerged macrophyte and culture conditions}

During the experiments, four strains of phytoplankton species were used: two cyanobacteria and two chlorophytes. The strain of $M$. aeruginosa (NPLJ-4) was obtained from the cyanobacteria culture collection at the Laboratory of Ecophysiology and Toxicology of Cyanobacteria, Federal University of Rio de Janeiro. In previous experiments with the same conditions of the present study, this strain was found to produce four variants of microcystins, mainly $\left[\mathrm{D}-\mathrm{Leu}^{-1}\right]$ microcystin-LR, with about $90 \%$ of the total microcystins, in addition to three other unknown variants (for details of toxin detection by High-Performance Liquid Chromatography see Amorim et al., 2017). A strain of $M$. panniformis Komárek et al. (BCCUSP29) was provided by the Brazilian Cyanobacteria Collection at the University of São Paulo and does not produce microcystins (Bittencourt-Oliveira, 2003). The chlorophyte strains, Ankistrodesmus falcatus (Corda) Ralfs (BMIUFRPE-01) and Raphidocelis subcapitata (Korshikov) Nygaard et al. (BMIUFRPE-02), were obtained from the Culture Collection of Microalgae from the Federal Rural University of Pernambuco - BMIUFRPE.

These strains were cultivated in ASM1 nutrient medium (Gorham et al., 1964), in a climatic chamber with controlled temperature $\left(25^{\circ} \mathrm{C} \pm 1.5\right)$, light intensity $\left(40 \mu \mathrm{mol}\right.$ photons $\left.\mathrm{m}^{-2} \cdot \mathrm{s}^{-1}\right), \mathrm{pH}(7.5)$, photoperiod $(12 \mathrm{~h})$, and the cultures were homogenized three times a day. The cultivations were kept until a biomass of approximately $50 \mathrm{mg} . \mathrm{L}^{-1}$ for cyanobacterial strains and $5 \mathrm{mg} . \mathrm{L}^{-1}$ for chlorophyte strains, during the exponential growth phase. These culture conditions were tested at the laboratory with higher growth for all tested phytoplankton species (e.g. Amorim, 2017; Amorim et al., 2017, 2019).

Young and photosynthetically active plants of $C$. demersum were collected from the Carpina Reservoir (latitude 753'08” S, and longitude $\left.35^{\circ} 20^{\prime} 42^{\prime \prime} \mathrm{W}\right)$, municipality of Lagoa do Carro, Pernambuco, Brazil. After collection, the plants were washed several times with a soft brush and distilled water jets to remove sediment, epiphyte microalgae, and zooplankton/zoobenthos, and cultivated in $8 \mathrm{~L}$ aquaria containing tap water, which was renewed weekly. Subsequently, they were cultivated in an aseptic and climatized room under the same conditions described for the culture of the strains, with constant aeration.

\subsection{Experimental design}

The coexistence experiment was carried out in an aseptic climatized room with the same conditions previously described for the culture of the strains. Eight treatments were used, each one with three replicates, totaling 24 experimental units, consisting of 1,000 mL Erlenmeyer flasks filled with $500 \mathrm{ml}$ of ASM1 cultivation medium. The coexistence treatments consisted of the cultivation of each strain with the addition of a young and apical branch of C. demersum to achieve biomass of $6.0 \mathrm{gFW} \cdot \mathrm{L}^{-1}$ ( $g$ of fresh weight per liter). Three days before the beginning of the experiment, the plants were washed five times with ultrapure water to remove algae and adhered animals and were subsequently kept in ASM1 medium for acclimatization. The control treatments consisted of the cultivation of each strain without $C$. demersum branches.

The experiment lasted six days and samples were taken to quantify the biomass of the strains every two days. For each sampling day, $2 \mathrm{~mL}$ aliquots were taken, which were fixed with $4 \%$ formalin for further density determination (cells. $\mathrm{mL}^{-1}$ ), by counting cells in a Fuchs-Rosenthal chamber. At least 400 cells per sample were counted to obtain a 90\% reliability degree (Lund et al., 1958). Then, the biomass $\left(\mathrm{mg} . \mathrm{L}^{-1}\right)$ was determined by multiplying the density by the average biovolume of the strains, using geometric formulas proposed by Sun \& Liu (2003). 


\subsection{Growth and inhibition rates}

Growth rates $(\mu)$ were calculated according to Wood et al. (2005): $\mu\left(\mathrm{d}^{-1}\right)=\left(\ln \left(\mathrm{N}_{\mathrm{t}}\right)-\ln \left(\mathrm{N}_{\mathrm{t} 0}\right)\right) / \mathrm{t}-\mathrm{t} 0$, where $\mathrm{N}$ represents the biomass values on the sixth day of the experiment $(\mathrm{t})$ and at the initial time $(\mathrm{t} 0)$. The inhibition rate (IR\%) was calculated as follows: $\operatorname{IR} \%=((\mathrm{Nm}-\mathrm{Nc}) / \mathrm{Nc}) \times 100$; where $\mathrm{N}_{\mathrm{m}}$ represents the biomass of the strains in the coexistence treatments with the macrophyte in each replicate, and $\mathrm{N}_{c}$ represents the mean biomass of the strains in the controls.

\subsection{Statistical analyses}

Significant differences in the biomasses of the strains were verified by the T-test between the treatments of coexistence and controls, for each strain and day of the experiment. Before the analyses, the data were tested for normality by the Shapiro test. A two-way ANOVA was performed to compare the differences in the growth rates between the species and the treatments. For that, the data were tested for normality and homoscedasticity using the Kolmogorov-Smirnov and Bartlett tests, respectively. The inhibition rates were compared between the strains separately for cyanobacteria and for chlorophytes by the T-test. Statistical analyses were performed in the $\mathrm{R}$ program, with a level of significance set at $p<0.05$ (R Core Team, 2016).

\section{Results}

\subsection{Effects of $C$. demersum on the biomass of the strains}

The submerged macrophyte $C$. demersum induced varied responses between the strains, both for the coexistence treatments with the cyanobacteria strains (producer and non-producer of microcystins), as well as with the chlorophytes. The biomass of the toxic $M$. aeruginosa strain was inhibited from the second day of coexistence with C. demersum to the end of the experiment, reaching a biomass close to zero on the sixth day (Figure 1a). However, the non-toxic strain of $M$. panniformis
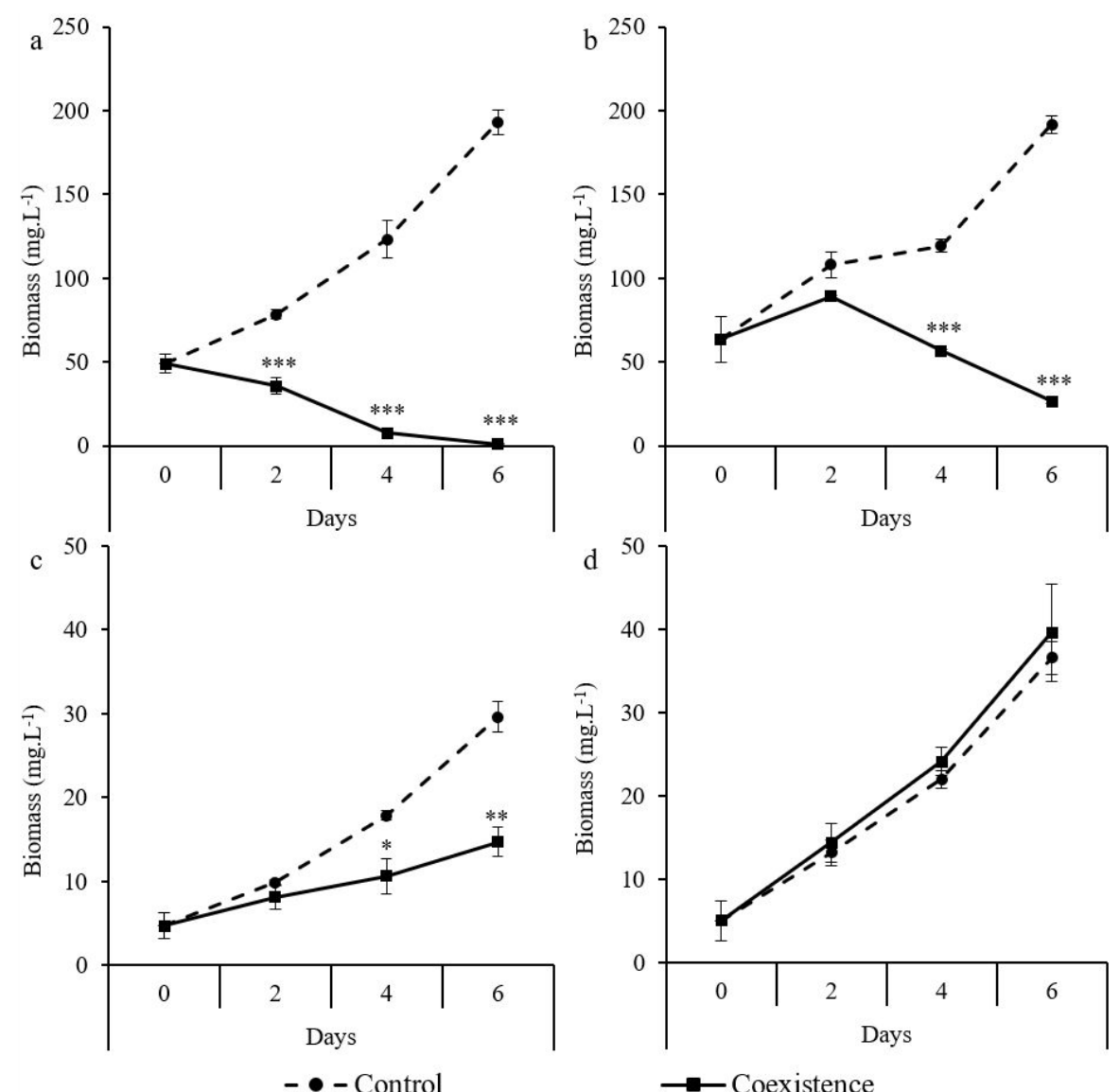

Figure 1. Biomasses of the strains of toxic Microcystis aeruginosa (a), non-toxic M. panniformis (b), Ankistrodesmus falcatus (c), and Raphidocelis subcapitata (d), submitted to the treatments of coexistence with Ceratophyllum demersum and control. Lines are the means and standard error. Significant differences between the coexistence and control treatments for each day are represented by asterisks (T-test, ${ }^{*} p<0.05 ;{ }^{* *} p<0.01 ;{ }^{* * *} p<0.001$ ). 
showed a less pronounced inhibition, with reductions in growth from the fourth to the sixth day of the experiment (Figure 1b). Both chlorophyte strains were less affected in relation to cyanobacteria. The strain of $A$. falcatus presented a delay in its growth, showing biomass lower than the control from the fourth day (Figure 1c). On the other hand, the strain of $R$. subcapitata was not affected by $C$. demersum in coexistence, with biomass similar to the control during all experiment (Figure 1d).

\subsection{Effects of $C$. demersum on the growth and inhibition rates of strains}

Both strains of Microcystis showed similar growth rates in the control treatment, with the non-toxic strain of $M$. panniformis presenting lower values $\left(0.18 \mathrm{~d}^{-1}\right)$ in relation to the toxic $M$. aeruginosa $\left(0.23 \mathrm{~d}^{-1}\right)$. In coexistence with $C$. demersum, both strains presented negative values, and showed a significant reduction in growth, being more pronounced in the toxic strain $\left(-0.65 \mathrm{~d}^{-1}\right)$ than in the non-toxic strain $\left(-0.15 \mathrm{~d}^{-1}\right)$. Both strains showed significant differences in the growth rates for the coexistence and control treatments $(\mathrm{p}<0.001)$ (Figure 2).

Both chlorophyte strains showed positive growth rates when co-cultivated with $C$. demersum and in the control. The strain of $A$. falcatus presented a significantly lower growth rate in the coexistence $\left(0.19 \mathrm{~d}^{-1}\right)$, when compared to the control $\left(0.31 \mathrm{~d}^{-1}\right)$

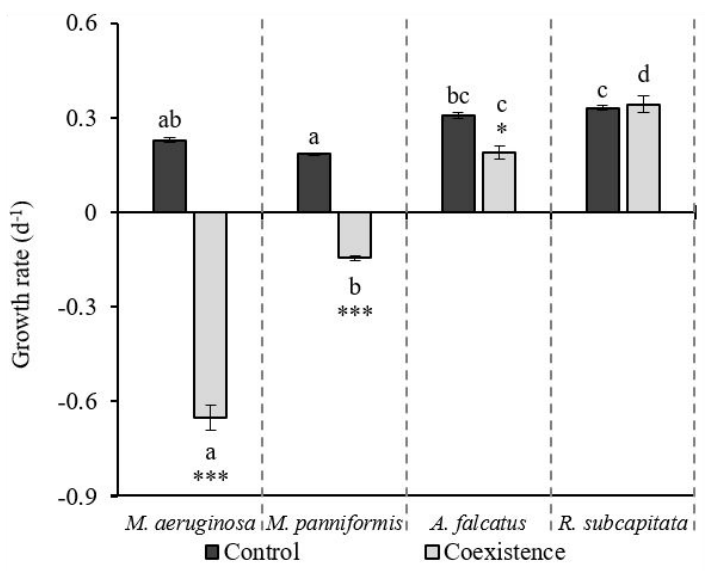

Figure 2. Growth rates of the strains of toxic Microcystis aeruginosa, non-toxic $M$. panniformis, Ankistrodesmus falcatus, and Raphidocelis subcapitata, submitted to the treatments of coexistence with Ceratophyllum demersum and control. Bars are the means and standard error. Different letters represent significant differences between the strains for each treatment (two-way ANOVA, $p<0.05$ ). Significant differences between the coexistence and control treatments for each strain are represented by asterisks (two-way ANOVA, ${ }^{*} p<0.05{ }^{* * *} p<0.001$ ).
( $\mathrm{p}<0.05$ ). In contrast, $R$. subcapitata did not show significant differences in the growth rates between the control $\left(0.33 \mathrm{~d}^{-1}\right)$ and coexistence $\left(0.34 \mathrm{~d}^{-1}\right)$ treatments $(\mathrm{p}>0.05)$ (Figure 2).

The growth rates of the strains showed significant differences between the treatments $(F=569.7$, $\mathrm{p}<0.001)$ and the species $(\mathrm{F}=316.7, \mathrm{p}<0.001)$. In the control, both strains of cyanobacteria showed similar growth, as well as both chlorophyte strains. All tested strains presented different growth rates when in coexistence with $C$. demersum, with $M$. aeruginosa presenting lower values, followed by $M$. panniformis, $A$. falcatus, and $R$. subcapitata (Figure 2).

When evaluating the inhibition rates, the high sensitivity of the tested cyanobacteria to allelochemicals of $C$. demersum, especially the toxic strain of $M$. aeruginosa, is evident, while the strains of chlorophytes were less sensitive. The toxic strain of $M$. aeruginosa was inhibited in $99.5 \%$, reaching biomass close to zero on the sixth day of the experiment in the coexistence treatment with $C$. demersum, while the non-toxic strain of $M$. panniformis was inhibited in $86.2 \%$. The chlorophyte strains were less affected by the allelochemicals of $C$. demersum. Ankistrodesmus falcatus was inhibited only in $50.4 \%$ when in coexistence with the macrophyte, while $R$. subcapitata was stimulated in $8.3 \%$. The inhibition rates of the strains showed significant differences between the strains for both cyanobacteria $(\mathrm{t}=24.89, \mathrm{p}<0.001)$ and chlorophytes $(\mathrm{t}=3.43, \mathrm{p}<0.05)$ (Figure 3$)$.

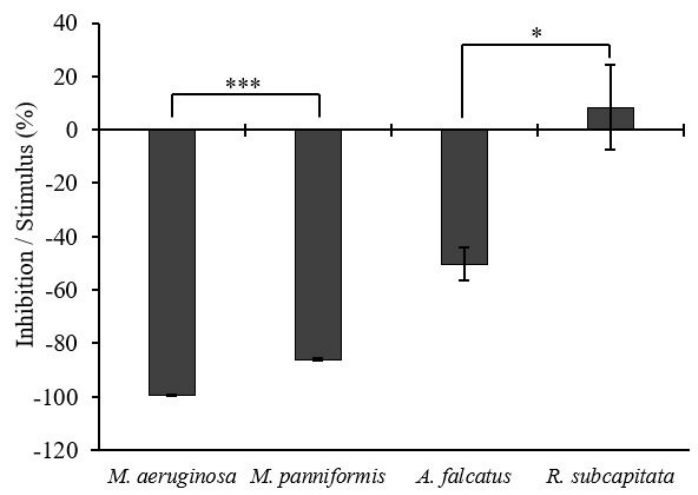

Figure 3. Inhibition rates of the strains of toxic Microcystis aeruginosa, non-toxic $M$. panniformis, Ankistrodesmus falcatus, and Raphidocelis subcapitata, submitted to the treatments of coexistence with Ceratophyllum demersum and control after six days. Bars are the means and standard error. Significant differences between the inhibition rates for both cyanobacteria strains and both chlorophyte strains are represented by asterisks (T-test, ${ }^{*} p<0.05$; $\left.{ }^{* * *} p<0.001\right)$. 


\section{Discussion}

The macrophyte $C$. demersum was able to allelopathically inhibit the growth of both cyanobacterial strains, more specifically the toxic $M$. aeruginosa, in relation to the non-toxic $M$. panniformis. In contrast, chlorophyte strains were less affected in coexistence with C. demersum, demonstrating lower sensitivity to the allelochemicals of this macrophyte. Nakai et al. (1999) also demonstrated the potential of this macrophyte in inhibiting allelopathically species of cyanobacteria, including $M$. aeruginos . In addition, Dong et al. (2014) showed that $C$. demersum can alter the structure of phytoplankton community from a eutrophic lake, promoting the dominance of chlorophytes, as well as inhibiting the growth of $M$. aeruginosa and benefiting the restoration of water quality for the lake.

Allelopathy can be observed in both terrestrial and aquatic plants. In aquatic ecosystems, submerged and floating plants, in addition to algae, play a primordial role in the local dynamics (Pflugmacher, 2002). In these environments, allelopathy occurs in all groups of macrophytes and algae, including cyanobacteria, and its effects are usually negative for other living organisms, commonly inhibiting the growth and photosynthesis of their competitors (Źak et al., 2012). However, Li et al. (2016) emphasize that, in addition to allelopathy, other factors, such as competition for light and nutrients, can give to the macrophytes a greater advantage in relation to cyanobacteria.

Allelopathically active macrophytes can be used in the restoration process of eutrophic aquatic environments, since these plants can control algal growth, especially of cyanobacteria (Gross et al., 1996; Ghobrial et al., 2015). Recently, many studies aiming to restore the water quality in eutrophic environments have been performed, especially using submerged macrophytes as a biomanipulation strategy (e.g. Dong et al., 2014; Vanderstukken et al., 2014; Yu et al., 2016; Liu et al., 2018). These plants have various mechanisms of action in these environments, particularly through the release of allelopathic compounds (Scheffer et al., 1993; Gross et al., 1996).

However, most studies conducted in laboratory use extracts of aquatic plants or purified allelochemicals (e.g. Li et al., 2016; Gao et al., 2017; Švanys et al., 2016), which often exceed the concentrations released by aquatic macrophytes in natural environments (Nakai et al., 1999). Therefore, studies about coexistence between aquatic macrophytes and phytoplankton more accurately reflect the reality of aquatic environments, as they elucidate other mechanisms involved in the inhibition of phytoplankton, such as competition for nutrients, light, or mechanical interference of plants.

According to Mohamed (2017), more than 40 aquatic macrophytes can inhibit phytoplankton species, and most studies have been developed using cyanobacterial strains, in particular, $M$. aeruginosa (e.g. Chen et al., 2012; Zhu et al., 2014; Gao et al., 2017). Other studies show that cyanobacteria are more sensitive to allelochemicals from aquatic macrophytes, followed by chlorophytes (Körner \& Nicklisch, 2002; Erhard \& Gross, 2006), as verified in the present study. The main mode of action of allelochemicals on cyanobacteria is the inhibition of photosystem II, through damage caused to the electron transport chain during photosynthesis, in addition to oxidative stress (Leu et al., 2002; Zhu et al., 2010; Gao et al., 2017).

During the experiments, the toxic strain of $M$. aeruginosa presented a higher inhibition by $C$. demersum when compared to the non-toxic strain of $M$. panniformis. Few studies show the allelopathic effects of submerged macrophytes on toxic and non-toxic strains, for example, Mulderij et al. (2005) showed that a toxic strain of $M$. aeruginosa was more sensitive to the exudates of Stratioides aloides L. than the non-toxic lineage. However, when evaluating the effects of tannic acid on several toxic and non-toxic strains of $M$. aeruginosa, Švanys et al. (2016) verified that non-toxic strains are more sensitive to this allelochemical, showing that something related to the synthesis of microcystins confers higher tolerance to toxic strains.

However, these studies were carried out by using purified exudates or allelochemicals, and in coexistence, it is possible that other factors contribute to the allelopathic responses of aquatic macrophytes over toxic and non-toxic strains. For example, when studying the allelopathic effects of Egeria densa Planch. on the same strains of Microcystis used in the present study, Amorim (2017) found that the microcystin-producing strain was inhibited by macrophyte allelochemicals, while the non-toxic strain was stimulated. Therefore, the presence of microcystins may act as a stress factor for aquatic macrophytes, which are stimulated to release a greater amount of allelochemicals in the medium that are toxic to Microcystis (Amorim, 2017). This justifies the greater sensitivity of the toxic strain of $M$. aeruginosa in the present study, which may have 
been exposed to a greater amount of allelochemicals than the non-toxic strain.

Several studies have shown the adverse effects of microcystins on submerged macrophytes. For example, Amorim et al. (2017) showed that the co-cultivation of $E$. densa with the same strains of Microcystis from the present study caused serious damage to the plant when exposed to toxic strains. This damages caused by the toxic strain was the reduction of the plant length and biomass, inhibition of the emission of shoots and roots, alteration in the content of photosynthetic pigments and oxidative stress, with a higher production of malondialdehyde and greater activity of enzymes catalase, superoxide dismutase and ascorbate peroxidase, while none of these alterations were verified in the co-cultivation with the non-toxic strain of $M$. panniformis and in the control (Amorim et al., 2017). Other studies also showed the adverse effects of microcystins or extracts of cyanobacterial blooms containing these toxins on the growth and physiological performance of $C$. demersum (e.g. Pflugmacher, 2004; Romero-Oliva et al., 2014, 2015a, b).

Unlike in Amorim (2017), the non-toxic strain of $M$. panniformis was not stimulated but showed a delay in growth during the initial days of the experiment. However, the reduction in biomass was less pronounced than in the toxic strain of $M$. aeruginosa, since the absence of microcystins did not stimulate the plant to release allelochemicals. However, at the end of the experiment, this strain was inhibited, with a negative growth rate, since the plant may have started releasing allelochemicals in response to nutrient limitation caused by the non-toxic strain, or the presence of other compounds such as lipopolysaccharide.

Both strains of chlorophytes were less affected from the beginning of the experiment by $C$. demersum. This fact can be justified by the absence of toxins, which did not stimulate the plant to release potentially toxic allelochemicals. In addition, some studies report the lower sensitivity of chlorophytes to allelochemicals of aquatic macrophytes, correlated to their physiology and adaptations to these compounds (Hilt \& Gross, 2008; Zhu et al., 2010).

In conclusion, the submerged macrophyte C. demersum inhibited both strains of cyanobacteria tested, being more markedly for the toxic $M$. aeruginosa than the non-toxic $M$. panniformis. Certainly, the greatest inhibition activity in the toxic strain was due to an intense release of allelochemicals by $C$. demersum in the treatment with this strain, since the presence of microcystins may have stressed the plant, resulting in higher production of allelochemicals. However, the chlorophyte strains were less affected in relation to cyanobacteria, showing delays in growth and demonstrating low sensitivity to the allelochemicals of aquatic macrophytes. In this sense, $C$. demersum could efficiently control toxic and non-toxic cyanobacterial blooms, without causing adverse effects to other phytoplankton organisms, such as chlorophytes.

\section{Acknowledgements}

We thank to the Programa de Pós-Graduação em Botânica from the Universidade Federal Rural de Pernambuco - UFRPE, the Conselho Nacional de Desenvolvimento Científico e Tecnológico (CNPq) for a productivity grant to ANM (Process 304237/2015-9); and the Fundação de Amparo à Ciência e Tecnologia do Estado de Pernambuco (FACEPE).

\section{References}

AMORIM, C.A. Efeitos alelopáticos mútuos entre a macrófita aquática Egeria densa Planch. e a cianobactéria formadora de florações Microcystis [Dissertação de Mestrado em Botânica]. Recife: Programa de Pósgraduação em Botânica, Universidade Federal Rural de Pernambuco, 2017.

AMORIM, C.A., ULISSES, C. and MOURA, A.N. Biometric and physiological responses of Egeria densa Planch. cultivated with toxic and non-toxic strains of Microcystis. Aquatic Toxicology, 2017, 191, 201-208. http://dx.doi.org/10.1016/j.aquatox.2017.08.012. PMid:28846860.

AMORIM, C.A., VALENÇA, C.R., MOURAFALCÃO, R.H. and MOURA, A.N. Seasonal variations of morpho-functional phytoplankton groups influence the top-down control of a cladoceran in a tropical hypereutrophic lake. Aquatic Ecology, 2019. In Press. http://dx.doi.org/10.1007/s10452019-09701-8.

BITTENCOURT-OLIVEIRA, M.C. Detection of potential microcystin-producing cyanobacteria in Brazilian reservoirs with a mcyB molecular marker. Harmful Algae, 2003, 2(1), 51-60. http://dx.doi. org/10.1016/S1568-9883(03)00004-0.

BITTENCOURT-OLIVEIRA, M.C., PICCINSANTOS, V., MOURA, A.N., ARAGÃOTAVARES, N.K. and CORDEIRO-ARAÚJO, M.K. Cyanobacteria, microcystins and cylindrospermopsin in public drinking supply reservoirs of Brazil. Anais da Academia Brasileira de Ciências, 2014, 86(1), 297-310. http://dx.doi.org/10.1590/00013765201302512. PMid:24676169. 
BRASIL. Ministério da Saúde. Portaria n 2914, de 12 de dezembro de 2011. Dispóe sobre os procedimentos de controle e de vigilância da qualidade da água para consumo humano e seu padrão de potabilidade. Diário Oficial da União [da] República Federativa do Brasil, Poder Executivo, Brasília, DF, 14 dez. 2011.

CARMICHAEL, W.W., AZEVEDO, S.M., AN, J.S., MOLICA, R.J., JOCHIMSEN, E.M., LAU, S., RINEHART, K.L., SHAW, G.R. and EAGLESHAM, G.K. Human fatalities from cyanobacteria: chemical and biological evidence for cyanotoxins. Environmental Health Perspectives, 2001, 109(7), 663-668. http://dx.doi.org/10.1289/ ehp.01109663. PMid:11485863.

CHANG, X., EIGEMANN, F. and HILT, S. Do macrophytes support harmful cyanobacteria? Interactions with a green alga reverse the inhibiting effects of macrophyte allelochemicals on Microcystis aeruginosa. Harmful Algae, 2012, 19, 76-84. http:// dx.doi.org/10.1016/j.hal.2012.06.002.

CHEN, J., ZHANG, H., HAN, Z., YE, J. and LIU, $Z$. The influence of aquatic macrophytes on Microcystis aeruginosa growth. Ecological Engineering, 2012, 42, 130-133. http://dx.doi.org/10.1016/j. ecoleng.2012.02.021.

CHORUS, I. and BARTRAM, J. Toxic cyanobacteria in water: a guide to their public health consequences, monitoring and management. Londres: E. \& F.N. Spon, 1999. http://dx.doi.org/10.4324/9780203478073.

DONG, J., YANG, K., LI, S., LI, G. and SONG, L. Submerged vegetation removal promotes shift of dominant phytoplankton functional groups in a eutrophic lake. Journal of Environmental Sciences, 2014, 26(8), 1699-1707. http://dx.doi. org/10.1016/j.jes.2014.06.010. PMid:25108726.

ERHARD, D. and GROSS, E.M. Allelopathic activity of Elodea canadensis and Elodea nuttallii against epiphytes and phytoplankton. Aquatic Botany, 2006, 85(3), 203-211. http://dx.doi.org/10.1016/j. aquabot.2006.04.002.

GAO, H., QIAN, X., WU, H., LI, H., PAN, H. and HAN, C. Combined effects of submerged macrophytes and aquatic animals on the restoration of a eutrophic water body: a case study of Gonghu Bay, Lake Taihu. Ecological Engineering, 2017, 102, 15-23. http://dx.doi.org/10.1016/j.ecoleng.2017.01.013.

GHOBRIAL, M.G., NASSR, H.S. and KAMIL, A.W. Bioactivity effect of two macrophyte extracts on growth performance of two bloom-forming cyanophytes. Egyptian Journal of Aquatic Research, 2015, 41(1), 69-81. http://dx.doi.org/10.1016/j. ejar.2015.01.001.

GORHAM, P.R., MCLACHLAN, J., HAMMER, U.T. and KIM, W.K. Isolation and culture of toxic strains of Anabaena flos-aquae (Lyngb.) de Bréb. Verhandlungen des Internationalen Verein Limnologie,
1964, 15(2), 796-804. http://dx.doi.org/10.1080/0 3680770.1962 .11895606$.

GROSS, E.M., MEYER, H. and SCHILLING, G. Release and ecological impact of algicidal hydrolysable polyphenols in Myriophyllum spicatum. Phytochemistry, 1996, 41(1), 133-138. http:// dx.doi.org/10.1016/0031-9422(95)00598-6. PMid:8987508.

HARKE, M.J., STEFFEN, M.M., GOBLER, C.J., OTTEN, T.G., WILHELM, S.W., WOOD, S.A. and PAERL, H.W. A review of the global ecology, genomics, and biogeography of the toxic cyanobacterium, Microcystis spp. Harmful Algae, 2016, 54, 4-20. http://dx.doi.org/10.1016/j. hal.2015.12.007. PMid:28073480.

HILT, S. and GROSS, E.M. Can allelopathically active submerged macrophytes stabilise clear-water states in shallow lakes? Basic and Applied Ecology, 2008, 9(4), 422-432. http://dx.doi.org/10.1016/j. baae.2007.04.003.

KÖRNER, S. and NICKLISCH, A. Allelopathic growth inhibition of selected phytoplankton species by submerged macrophytes. Journal of Phycology, 2002, 38(5), 862-871. http://dx.doi. org/10.1046/j.1529-8817.2002.t01-1-02001.x.

KOSTEN, S., HUSZAR, V.L.M., BÉCARES, E., COSTA, L.S., DONK, E., HANSSON, L.A., JEPPESEN, E., KRUK, C., LACEROT, G., MAZZEO, N., MEESTER, L., MOSS, B., LÜRling, M., NÓGES, T., ROMO, S. and SCHEFFER, M. Warmer climates boost cyanobacterial dominance in shallow lakes. Global Change Biology, 2012, 18(1), 118-126. http://dx.doi. org/10.1111/j.1365-2486.2011.02488.x.

LEU, E., KRIEGER-LISZKAY, A., GOUSSIAS, C. and GROSS, E.M. Polyphenolic allelochemicals from the aquatic angiosperm Myriophyllum spicatum inhibit photosystem II. Plant Physiology, 2002, 130(4), 2011-2018. http://dx.doi.org/10.1104/pp.011593. PMid:12481084.

LI, J., LIU, Y., ZHANG, P., ZENG, G., CAI, X., LIU, S., YIN, Y., HU, X., HU, X. and TAN, X. Growth inhibition and oxidative damage of Microcystis aeruginosa induced by crude extract of Sagittaria trifolia tubers. Journal of Environmental Sciences, 2016, 43, 40-47. http://dx.doi.org/10.1016/j. jes.2015.08.020. PMid:27155407.

LIU, Z., HU, J., ZHONG, P., ZHANG, X., NING, J., LARSEN, S.E., CHEN, D., GAO, Y., HE, H. and JEPPESEN, E. Successful restoration of a tropical shallow eutrophic lake: strong bottom-up but weak top-down effects recorded. Water Research, 2018, 146, 88-97. http://dx.doi.org/10.1016/j. watres.2018.09.007. PMid:30236468.

LORENZI, A.S., CORDEIRO-ARAÚJO, M.K., CHIA, M.A. and BITTENCOURT-OLIVEIRA, M.C. Cyanotoxin contamination of semiarid 
drinking water supply reservoirs. Environmental Earth Sciences, 2018, 77(16), 595. http://dx.doi. org/10.1007/s12665-018-7774-y.

LUND, J.W.G., KIPLING, C. and LE CREN, E.D. The inverted microscope method of estimating algal numbers and the statistical basis of estimations by counting. Hydrobiologia, 1958, 11(2), 143-170. http://dx.doi.org/10.1007/BF00007865.

MOHAMED, Z.A. Macrophytes-Cyanobacteria allelopathic interactions and their implications for water resources management-a review. LimnologicaEcology and Management of Inland Waters, 2017, 63, 122-132. http://dx.doi.org/10.1016/j. limno.2017.02.006.

MOURA, A.N., ARAGÁO-TAVARES, N.K.C. and AMORIM, C.A. Cyanobacterial blooms in freshwater bodies from a semiarid region, Northeast Brazil: a review. Journal of Limnology, 2018, 77(2), 179-188. http://dx.doi.org/10.4081/ jlimnol.2017.1646.

MULDERIJ, G., MOOIJ, W.M., SMOLDERS, A.J.P. and VAN DONK, E. Allelopathic inhibition of phytoplankton by exudates from Stratiotes aloides. Aquatic Botany, 2005, 82(4), 284-296. http://dx.doi. org/10.1016/j.aquabot.2005.04.001.

MULDERIJ, G., VAN NES, E.H. and VAN DONK, E. Macrophyte-phytoplankton interactions: the relative importance of allelopathy versus other factors. Ecological Modelling, 2007, 204(1-2), 85-92. http:// dx.doi.org/10.1016/j.ecolmodel.2006.12.020.

NAKAI, S., INOUE, Y., HOSOMI, M. and MURAKAMI, A. Growth inhibition of blue-green algae by allelopathic effects of macrophytes. Water Science and Technology, 1999, 39(8), 47-53. http:// dx.doi.org/10.2166/wst.1999.0382.

PAERL, H.W. and OTTEN, T.G. Harmful cyanobacterial blooms: causes, consequences, and controls. Microbial Ecology, 2013, 65(4), 995-1010. http://dx.doi.org/10.1007/s00248-012-0159-y. PMid:23314096.

PFLUGMACHER, S. Possible allelopathic effects of cyanotoxins, with reference to microcystin-LR, in aquatic ecosystems. Environmental Toxicology, 2002, 17(4), 407-413. http://dx.doi.org/10.1002/ tox.10071. PMid:12203964.

PFLUGMACHER, S. Promotion of oxidative stress in the aquatic macrophyte Ceratophyllum demersum during biotransformation of the cyanobacterial toxin microcystin-LR. Aquatic Toxicology, 2004, 70(3), 169-178. http://dx.doi.org/10.1016/j. aquatox.2004.06.010. PMid:15550274.

R CORE TEAM. $R$ : a language and environment for statistical computing [online]. Vienna: R Foundation for Statistical Computing, 2016 [viewed 7 Feb. 2019]. Available from: https://www.R-project.org/
ROMERO-OLIVA, C.S., CONTARDO-JARA, V. and PFLUGMACHER, S. Antioxidative response of the three macrophytes Ceratophyllum demersum, Egeria densa, and Hydrilla verticillata to a time dependent exposure of cell-free crude extracts containing three microcystins from cyanobacterial blooms of Lake Amatitlan, Guatemala. Aquatic Toxicology, 2015a, 163, 130-139. http://dx.doi.org/10.1016/j. aquatox.2015.04.001. PMid:25889089.

ROMERO-OLIVA, C.S., CONTARDO-JARA, V. and PFLUGMACHER, S. Time dependent uptake, bioaccumulation and biotransformation of cell free crude extract microcystins from lake Amatitlan, Guatemala by Ceratophyllum demersum, Egeria densa and Hydrilla verticillata. Toxicon, 2015b, 105, 62-73. http://dx.doi.org/10.1016/j.toxicon.2015.08.017. PMid:26325293.

ROMERO-OLIVA, C.S., CONTARDO-JARA, V., BLOCK, T. and PFLUGMACHER, S. Accumulation of microcystin congeners in different aquatic plants and crops: a case study from lake Amatitlán, Guatemala. Ecotoxicology and Environmental Safety, 2014, 102, 121-128. http://dx.doi.org/10.1016/j. ecoenv.2014.01.031. PMid:24530727.

SCHEFFER, M., HOSPER, S.H., MEIJER, M.L., MOSS, B. and JEPPESEN, E. Alternative equilibria in shallow lakes. Trends in Ecology \& Evolution, 1993, 8(8), 275-279. http://dx.doi.org/10.1016/01695347(93)90254-M. PMid:21236168.

SCHEFFER, M., SZABÓ, S., GRAGNANI, A., VAN NES, E.H., RINALDI, S., KAUTSKY, N., NORBERG, J., ROIJACKERS, R.M.M. and FRANKEN, R.J.M. Floating plant dominance as a stable state. Proceedings of the National Academy of Sciences of the United States of America, 2003, 100(7), 4040-4045. http://dx.doi.org/10.1073/ pnas.0737918100. PMid:12634429.

SUN, J. and LIU, D. Geometric models for calculating cell biovolume and surface area for phytoplankton. Journal of Plankton Research, 2003, 25(11), 1331 1346. http://dx.doi.org/10.1093/plankt/fbg096.

ŠVANYS, A., EIGEMANN, F., GROSSART, H.P. and HILT, S. Microcystins do not necessarily lower the sensitivity of Microcystis aeruginosa to tannic acid. FEMS Microbiology Letters, 2016, 363(2), fnv227. http://dx.doi.org/10.1093/femsle/fnv227. PMid:26613927.

VANDERSTUKKEN, M., DECLERCK, S.A., DECAESTECKER, E. and MUYLAERT, K. Long-term allelopathic control of phytoplankton by the submerged macrophyte Elodea nuttallii. Freshwater Biology, 2014, 59(5), 930-941. http:// dx.doi.org/10.1111/fwb.12316.

WIEGAND, C. and PFLUGMACHER, S. Ecotoxicological effects of selected cyanobacterial secondary metabolites a short review. Toxicology and Applied Pharmacology, 2005, 203(3), 201-218. 
http://dx.doi.org/10.1016/j.taap.2004.11.002. PMid: 15737675.

WOOD, A.M., EVERROAD, R.C. and WINGARD, L.M. Measuring growth rates in microalgal cultures. In. R.A. ANDERSEN, ed. Algal culturing techniques. Singapore: Academic Press/Phycological Society of America, 2005, pp. 269-285.

YU, J., LIU, Z., LI, K., CHEN, F., GUAN, B., HU, Y., ZHONG, P., TANG, Y., ZHAO, X., HE, H., ZENG, H. and JEPPESEN, E. Restoration of shallow lakes in subtropical and tropical China: response of nutrients and water clarity to biomanipulation by fish removal and submerged plant transplantation. Water, 2016, 8(10), 438. http://dx.doi.org/10.3390/ w8100438.

ŻAK, A., MUSIEWICZ, K. and KOSAKOWSKA, A. Allelopathic activity of the Baltic cyanobacteria against microalgae. Estuarine, Coastal and Shelf Science, 2012, 112, 4-10. http://dx.doi.org/10.1016/j. ecss.2011.10.007.

ZHU, J., LIU, B., WANG, J., GAO, Y. and WU, Z. Study on the mechanism of allelopathic influence on cyanobacteria and chlorophytes by submerged macrophyte (Myriophyllum spicatum) and its secretion. Aquatic Toxicology, 2010, 98(2), 196-203. http://dx.doi.org/10.1016/j.aquatox.2010.02.011. PMid:20451264.

ZHU, Z., LIU, Y., ZHANG, P., ZENG, G., HU, X., LI, H., GUO, Y. and GUO, X. Co-culture with Cyperus alternifolius induces physiological and biochemical inhibitory effects in Microcystis aeruginosa. Biochemical Systematics and Ecology, 2014, 56, 118-124. http://dx.doi.org/10.1016/j. bse.2014.05.008.

ZUO, S., MEI, H., YE, L., WANG, J. and MA, S. Effects of water quality characteristics on the algicidal property of Alternanthera philoxeroides (Mart.) Griseb. in an aquatic ecosystem. Biochemical Systematics and Ecology, 2012, 43, 93-100. http://dx.doi. org/10.1016/j.bse.2012.03.003.

Received: 07 February 2019 Accepted: 15 July 2019 